\title{
CLIL in the Foreign Language Classroom: Proposal of a Framework for ICT Materials Design in Language-Oriented Versions of Content and Language Integrated Learning
}

\author{
Almudena Fernández Fontecha \\ La Rioja University \\ almudena.fernandez@unirioja.es
}

\begin{abstract}
A shortage of materials and guidelines that link CLIL theory to classroom practice has been reported in research about the European context. In all versions of CLIL implementation, the sequence of non-linguistic contents should be the point of departure for the sequence of linguistic contents. However, the teacher's previous work to materials delivery will differ depending on the particularities of each possible CLIL scenario. In contentoriented versions of CLIL, the non-linguistic contents are already set in the official curriculum. In language-oriented versions, the language teacher has to define the sequence of non-linguistic contents by preserving the objectives of the foreign language curriculum. This paper describes the Content and Language Processing Sequence (CLPS), a tool devised for supporting the selection of non-linguistic contents, the treatment of the language component, and the design of ICT materials in a CLIL model for the foreign language classroom.
\end{abstract}

\section{Introduction}

Inspired by the Canadian immersion programme and the United States content-based instruction, Content and Language Integrated Learning (CLIL) is an educational 
approach to foreign language teaching in which the linguistic form ceases to be an end in itself and becomes the means to express non-linguistic contents. In recent years, it has become a priority in the European language policy (Marsh, Maljers, and Hartiala, 2001; Eurydice, 2006; Marsh, 2002). Since its rise in the European context, numerous empirical studies have been conducted on its effectiveness, for example, regarding language achievement - see Dalton-Puffer (2008) for a review of current CLIL-oriented research in Europe. By contrast, CLIL pedagogical issues have not received the same attention. For example, recent research has identified a serious lack of tools and models of CLIL implementation and materials design (Räsänen, Kaasik, Mathews, Oresik, and Sentocnik, 1996; Hartiala, 2000; Fernández, Pena, García, and Halbach, 2005; Llovet 2007; Fernández Fontecha, 2008b).

Content and Language Integrated Learning (CLIL) has been adopted as an umbrella term that encompasses a variety of content and language-oriented models. Independently of this variation, CLIL teachers themselves are often in charge of translating the CLIL principles into adequate practice by planning and designing the CLIL syllabus as well as the activities or tasks through which CLIL is realized. With some exceptions, the existing literature on CLIL pedagogy focuses on content-oriented models of CLIL. In general, in these models the CLIL teacher does not need to select the CLIL contents since they are already dictated by an official curriculum. However, the implementation of a language-oriented version of CLIL in the foreign language classroom demands from the language teacher some work different from that required in content-oriented versions of CLIL. This kind of work involves a series of tasks prior to materials design, such as content selection, adaptation and sequencing, along with the treatment of the foreign language and its integration into the content sequence.

In order to compensate for the absence of CLIL pedagogical tools in all types of CLIL but especially in language-oriented models, we put forward the design of a framework that could aid teachers in CLIL syllabus planning and materials design. The framework attempts to give an answer to aspects including the selection of contents or the treatment of the foreign language in a language-oriented version of CLIL.

\section{Language-oriented CLIL}

In the Spanish CLIL, most programmes follow a type of sheltered content instruction model, a strong version of CLIL where the instruction is done exclusively by the content specialist (Fernández Fontecha, 2009). In this model, the CLIL teacher is required to have a double qualification both in content and language. However, if we take into account the current situation of teachers in many Spanish regions concerning pre and in-service training, in many cases this seems a somewhat unrealistic goal (Fernández Fontecha, 2010a). A more viable alternative to this model nowadays could be the adjunct model, in which a content teacher instructs the students in the Foreign Language (FL) and the language teacher offers support to the content class. Some syllabus adaptation should be required here. This is the option recommended by the 
Junta de Andalucía (2008) in the Currículo integrado de las lenguas. Apart from these variants of CLIL, Brinton, Snow and Wesche (2004) describe the theme-based language instruction as a third option. This is the weakest version of CLIL, where the FL teacher carries out the instruction.

As Nikula (1997) notes, although the different CLIL models refer to the same phenomena, they differ in the emphasis placed on the language and content. These and other variants represent different points along a content-language oriented continuum (Met, 1998). In content-oriented or strong models of CLIL, the non-linguistic contents dictate the sequence of the language contents. In language-oriented or weak models, the language sequence still depends on the content sequence but it has a larger role than in content-oriented models: the language covertly monitors the content, as the linguistic objectives are the basis of the FL syllabus.

Theme-based language instruction (Brinton et al., 2004), theme-based instruction (Raphan and Moser, 1993/1994), thematic teaching (Curtain and Haas, 1995), or content-based thematic units (Irujo, 1990) are some of the terms referring to languageoriented CLIL models. The focus of this approach is primarily on the foreign language. Thus, the target of evaluation will be language skills and functions. The instructional format is a content-oriented L2/FL course. The language teacher is in charge of language and content instruction. At least, following Brinton et al. (2004), in this model there is no need for cooperation between mainstream teachers and language specialists. The curriculum is based on thematic units that cover a wide variety of topics that may integrate the four language skills. Curtain and Haas (1995: 3) explain that "the thematic center may be a curriculum area, such as the Middle Ages; a word like 'inside'; a theme such as horses; or a story in the target language." Language-oriented CLIL seems to be forgotten in official Spanish CLIL programmes, which advocate exclusively for strong versions of CLIL.

In this model, it is not easy to find a textbook suitable for the instruction of the units. A possible solution could be that the teachers design their own materials. In this situation, some set of guidelines that inform the process towards materials design would be desirable. In generating a CLIL syllabus, some CLIL guidelines should back the interaction of the linguistic and non-linguistic contents stated in the official curricula. This process would entail the selection, processing, and sequencing of non-linguistic contents together with the treatment of linguistic contents and the relationship between both content and language.

\section{CLIL Tools}

Since the 1980s, a large number of tools have been devised in the North American context that cover different steps of language and content integration. Some of the bestknown tools are Chamot and O'Malley's (1987, 1994) CALLA Approach, Kidd and Marquardson's (1993, 1994) Foresee Approach, Snow et al.'s (1989) Conceptual Framework, Cummins's (1998) framework for pedagogy in immersion programmes, 
Echevarria, Vogt, and Short's (2000) SIOP Model, and Mohan's (1986) Knowledge Framework. Other authors do not provide a whole framework but some valid tools or techniques, e.g. Martin's (1990) notion of thematic module, or Gianelly (1997) recommendations on how to sequence a content-based language curriculum into thematic units, by selecting themes, identifying content area concepts, or identifying the skills to be emphasized, among others.

Due to the recent experience of European CLIL, not many frameworks are found in this context. Here, some professional training programmes have been published: Marsh and Marsland's (1999) and Langé's (2002) professional development programmes, and ALPME, the Advanced Level Programme in Multilingual Education. More recently, two handbooks offer assistance in the application of teaching techniques and theoretical principles in activities design at different educational levels: Coyle, Hood and Marsh (2010) and Mehisto, Marsh, and Frigols (2008).

These tools are useful sets of instructions about how to manage different parts of the CLIL implementation process, e.g. content and language assessment, use of visuals, identification of knowledge structures, inclusion of thinking skills - see Fernández Fontecha (2008a) for a review of each of these tools. Yet, a couple of issues should be noted here: first, most of these tools address adjunct or sheltered instruction CLIL models; few focus on the problems of the language teacher as a CLIL teacher in a theme-based model. And second, none of the above-mentioned tools include a regular use of the Information and Communication Technologies (ICT) in CLIL provision. In our view, CLIL materials design could well benefit from the combination of ICT and CLIL. The use of the ICT component may help develop the different postulates of CLIL. Thus, it could provide quantity and quality of exposure to the foreign/second language, motivation, and rich visual support to content and language learning; it could trigger cooperative forms of learning and learning by doing; and it could help develop language learning skills and higher-order thinking skills. CLIL may indirectly help create favourable conditions for ICT integration, an aspect forgotten in many respects in current foreign/second language teaching, as noted by different authors (e.g. Gillespie and McKee, 1999; McCarthy, 1999; Bax, 2003; Richards, 2005). Among the different possible ways of attaining ICT integration, Chambers and Bax (2006) point to the systematic inclusion of the new technologies in syllabus design. The combination of CLIL and ICT has already been recommended in the literature (Opp-Beckman, 2002; Reinhardt and Isbell, 2002; Pérez Torres, 2006; Levy, 2007; Stoller, 2008) but it needs further development.

In this paper, we propose the Content and Language Processing Sequence (CLPS), a tool that could inform aspects such as the selection and processing non-linguistic contents, language treatment, and materials design in a language-oriented version of CLIL developed by the FL teacher in the FL classroom. The product developed by means of the CLPS is the CLILQuest, an ICT-based task that becomes the unit of learning in this model. 


\section{The Content and Language Processing Sequence (CLPS)}

\subsection{Definition and features}

The type of CLIL syllabus intended through the tool we propose here is based on a sequence of three distinct graded categories: Topic, Module, and CLILQuest. This sequence receives the name of Content and Language Processing Sequence (CLPS). It seeks to systematize the teacher's task of integrating content and language before instruction delivery.

The following features define the tool or framework that we propose:

Systematic guidance: the tool attempts to work as a guide for the CLIL teacher in attempting to provide the means to overcome the difficulties that may arise from the combination of content and language.

Promotion of language-oriented versions of CLIL: although the tool may fit in any sort of CLIL scenario, it is particularly useful in monitoring language-oriented versions of CLIL, wherein the focus stays on the language rather than on the content and the foreign language teacher undertakes CLIL implementation. Hence, the framework might be especially helpful for foreign language classes where no official document prescribes the use of a fixed set of non-linguistic contents.

Immediate classroom application: by following the steps specified in the framework, the teacher will obtain a material for immediate delivery in the classroom. The framework is essentially practical in nature and strongly related to the teachers' work experience.

Teacher-managed: the framework assigns a crucial role to the teacher. It presupposes the teacher's implication in the creation of instructional materials. The framework places the CLIL teacher in an adequate position to control each element involved in this process. In this context, the textbook becomes just one of the many resources that may supplement the instruction.

Learner-centred: the learner is implicit in each decision made in the organization of the syllabus and the creation of materials. Due to the communicative nature of the methodological approaches connected in our framework, the learner's characteristics are essential aspects to the process.

ICT integration through systematic use: suffice to say that any CLIL model can do well without the incorporation of technological aids. However, we confer a central role on ICT in the design process as it can increase the possibilities of CLIL and facilitate its provision. Its function is not anecdotal.

\subsection{Sources of inspiration}

Our framework is influenced by some of the abovementioned tools and sets of recommendations, e.g. Mohan's Knowledge Framework, Martin's (1990) thematic modules, or Chamot and O'Malley's $(1987,1994)$ CALLA Aproach, and others sources 
such as Anderson and Krathwohl's revision of Bloom's taxonomy of educational objectives (2001).

Mohan's (1986) Knowledge Framework is based on the idea that each activity involves some theoretical and practical knowledge and is shaped by some knowledge structure. These structures are ways in which knowledge is organized in discourse. They require different linguistic features. Mohan points to description, sequence and choice as knowledge structures that serve to develop the theoretical part of an activity, and classification, principles and evaluation as structures of the practical part of an activity.

The second reference that inspires this work is Martin (1990). This author proposes the thematic module as the basic unit of study in a content-based language course midway between the lesson and the course. Built upon a general input-treatment-output structure, they follow a task-based approach in which input is potentially comprehensible, carefully selected, interesting to learners, and it should lead the learners into greater depth of understanding of the topic. This input should be teacherdeveloped and kept as one of a module-bank of materials and activities that are continually refreshed and re-evaluated.

Finally, Chamot and O'Malley's Cognitive Academic Language Learning Approach includes learning strategies component in content-based language learning. Grounded in cognitive and educational psychology, a common recommendation in CLIL models is the introduction of the study of language learning strategies and higherorder thinking skills as supporting tools for achieving academic language proficiency (Cummins, 1980, 1984). See Mehisto, Marsh and Frigols (2008: 154-155) for examples on the use of some of these taxonomies of educational objectives.

Apart from Marzano's (2001), one of the best known taxonomies of educational objectives is Bloom's (1956), which includes the following thinking skills: knowledge (recall information), comprehension (understand the meaning of a concept), application (use the information or concepts in new situations), analysis (break information or concepts into different parts for better understanding), synthesis (put ideas together to form new knowledge), and evaluation (make judgments based on criteria and standards). In this model, the latter skills are more cognitively demanding than the former ones. Anderson and Krathwohl (2001) provide a revision of Bloom's taxonomy. This new taxonomy relies upon two distinct dimensions: the knowledge dimension and the cognitive process dimension. The knowledge dimension includes four categories of knowledge. These are: factual knowledge, i.e. the basic elements students must know to be acquainted with a discipline or solve problems in it; conceptual knowledge, i.e. the interrelationships among the basic elements within a larger structure that enables them to function together; procedural knowledge, i.e. how to do something, methods of inquiry, and criteria for using skills, algorithms, techniques, and methods; metacognitive knowledge, i.e. knowledge of cognition in general as well as awareness and knowledge of one's own cognition. The cognitive process dimension includes Bloom's taxonomy of thinking skills with some terminological variations, such as remember (Bloom's knowledge), understand (Bloom's comprehension), apply, analyze, 
evaluate, and create (Bloom's synthesis). Using this double dimension structure, the teacher may specify the educational objectives by selecting one type of knowledge in the knowledge dimension and one type of thinking skill in the cognitive dimension. The knowledge domain in this taxonomy could be useful for defining types of non-linguistic contents.

\subsection{Components}

Topic

For Kidd and Marquardson (1993), the first step in CLIL syllabus design is topic selection. In general, a topic can be defined as what is being talked about. When a topic does not correspond to a subject, i.e. it is not determined by a national curriculum, its selection should follow a set of criteria. Two core criteria are that the topic should motivate learners and it should have some social interest. Apart from that, the teachers should think whether the conceptual load and the difficulty that the subject has, along with its instruction in a language different from the mother tongue, would make things extremely complex for learners. Moreover, the linguistic part of a topic should be controlled whenever possible. We consider that this idea should be a must in CLIL scenarios where learners are assessed on language. Each topic has linguistic potential inasmuch as its concepts and meanings are transmitted by no other means than language. However, based on aspects such as the moment at which the instruction of the topic takes place, or the relationship of the topic with the previous and subsequent teaching of other topics, it is the teacher's decision to find the linguistic part of a topic adequate or not. Everything taken into account, we deem it necessary to establish some procedures and provide some means, guidelines, or strategies to safeguard the linguistic side of a particular content.

Topics could be divided into subtopics, immediate smaller categories of content. The topic-subtopic relationship resembles the traditional relation of subject and units. A crucial feature in selecting a subtopic is that it should render the essential information of the topic.

\section{Module}

Each topic or subtopic is developed through a series of modules. Drawn on Martin's (1990) notion of thematic module, i.e. basic units of study in a content-based language course midway between the lesson and the course, the module in our framework corresponds to distinct categories of knowledge behind the topic. Based on Anderson and Krathwohl's (2001) dimension of knowledge within their adaptation of Bloom's (1956) taxonomy of educational objectives, we distinguish a sequence of at least four categories of modules arranged into two axes: the Background Knowledge Axis and the Practical Knowledge Axis. The former includes the main theory underlying the topic or the factual and conceptual knowledge in Anderson and Krathwohl's model. The latter contains the topic's procedural knowledge in Anderson and Krathwohl's terms. Both axes stand in a complementary relationship. This means that, for learners to gain full 
insight into the topic, the theoretical and more abstract knowledge found in the background knowledge axis should find support in the practical examples, concrete situations, and cases of the practical knowledge axis. On the other hand, the practical knowledge needs to be grounded into a wider context, which is provided by the theoretical knowledge. Declarative and procedural knowledge are two of the learner's general competences pointed out in the CEF (Council of Europe, 2001). Both types of knowledge are also present in Mohan's (1986) Knowledge Framework, where different knowledge structures are defined on the semantic relations that underlie text. However, in Mohan's model, they are exclusively language-dependent, i.e. the occurrence of specific knowledge structures, such as classification, choice, or description, depends exclusively on the discourse features found in a text. Differently from Mohan's model, the introduction of knowledge structures in our framework depends on content requirements rather than on language.

These are the four types of modules profiled:

Background Knowledge Axis

1. Introductory Module: the purpose of this category of modules is to introduce the main concepts and ideas of the topic. Modules of this kind must be especially motivating in this initial phase in order to draw students' attention towards the topic presented. A critical characteristic of Introductory Modules is that they should activate learners' background information on the topic.

2. Core-Knowledge Module: these modules contain the essential information for understanding the topic.

Practical Knowledge Axis

3. Case Module: they develop the topic through concrete examples. Their main purpose is to depict the reality behind the background knowledge of each topic.

4. Awareness Module: these modules attempt to develop the same procedural knowledge as Case Modules. Learners apply the knowledge acquired in the Background Knowledge Axis to problems related to their lives. They aim to raise students' awareness towards topic-specific problems. Awareness Modules are particularly important for the teaching of moral contents.

We deem it of utmost importance that the teacher keeps the established order of the sequence of modules as a means of controlling the occurrence of both theoretical and practical knowledge to the maximum. In this sense, we recommend to use a complete modular sequence for each topic. However, there is no limit in using more than one sequence as long as each category of module is introduced. In addition, one sequence can be adapted to the particularities of each teaching situation. This means that for some specific purposes we can devise sets of more than one module of each category for a given topic.

\section{CLILQuest}

The last category of the CLPS is the CLILQuest (Fernández Fontecha, 2010b). It receives the name after Dodge (2001) and March's (2000, 2003) idea of WebQuest. Like the WebQuest, the CLILQuest is an inquiry-oriented activity that draws on the 
resources of the Internet and promotes the development of learners' higher-order thinking skills. Like language-specific WebQuests (e.g. Pérez Torres, 2006; Koenraad and Westhoff, 2003), CLILQuests' main function is to help learners use the foreign language with a purpose by means of authentic Web information. Yet, the CLILQuest differs from the language-specific WebQuests in that (1) it is specifically embedded in a CLIL syllabus, (2) it approaches the four language skills from a holistic perspective, and (3) it belongs to a sequence and it is embedded within a superior component. This latter factor enables the actual integration of ICT into the CLIL syllabus as CLILQuests depend on the requirements of the topics and modules.

It is strongly motivated by Jonassen's (1994) Constructivist Learning Environments and the constructivist learning designs noted by Oliver (2001), i.e. problem-based learning, case-based learning, project-based learning, inquiry-based learning, and roleplaying. It is also influenced by the Task Based Language Teaching (TBLT) methodological principles developed by Doughty and Long (2003). For example, following these authors, the CLILQuest allows for a meaningful integration of some Focus on Form (FonF) techniques.

There are four types of CLILQuests, which coincide with each of the four types of modules profiled above, i.e. Introductory, Core-Knowledge, Case, and Awareness CLILQuest. Each CLILQuest consists of the following sections: guide, test, development, general and a scaffold/web resources section. In the guide, the task type and the participants' roles are specified. Influenced by Long (1998) task types, they are more abstract categories that serve to agglutinate specific tasks. Each task type may correspond to one or several of the constructivist learning designs pointed out by Oliver (2001). The test section seeks (1) to activate learners' background knowledge on a given subtopic, and (2) enable the connection of foreign language vocabulary and structures to those of the first language by means of FonF techniques. In the development section, each of the quests, or specific tasks that develop the task type of each CLILQuest, are described. The quest section includes the participants' teams, the quest's main goals and intended outcomes, and the list of web resources and additional documentation. Figure 1 shows the structure of the CLPS.

\subsection{The operating CLPS}

The nature of CLIL requires us to find a workable solution to interrelate content and language. In this section, we suggest a number of steps that the teacher could follow in working with content and language before and during materials design. The process begins in the content domain. This is a one-way process that gives the content a primary role. In CLIL, the topic is the starting point for decisions on the learning task, as well as the organizing agent of the whole process. Changes occurring in a content step affect the next language step. Following, we explain the way the teacher in language-oriented CLIL could work with content and language from topic selection to materials design: 

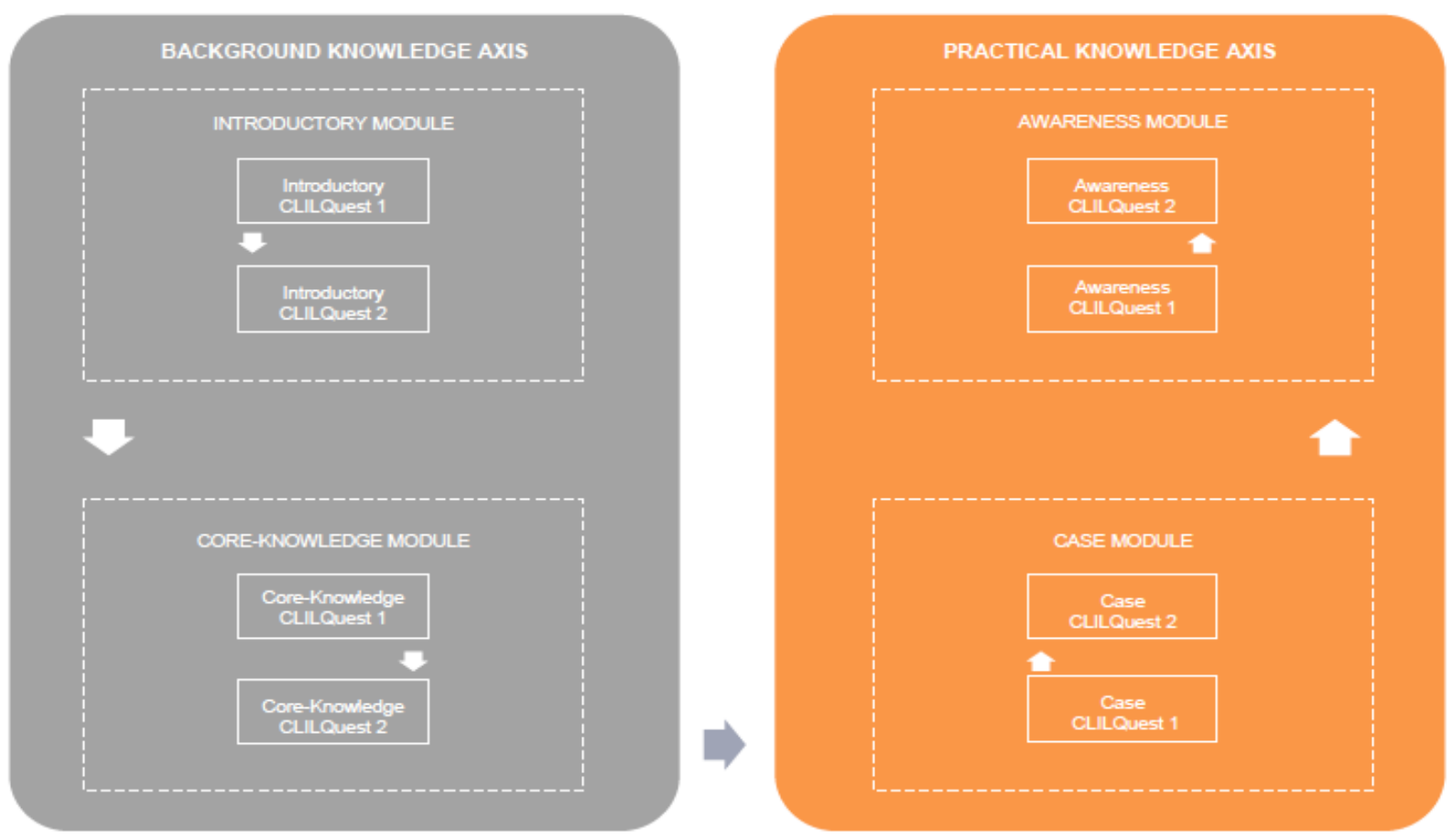

Figure 1. The Content and Language Processing Sequence (CLPS) (Fdez Fontecha, 2010: 55)

\section{Step 1. Topic selection}

The selection of a topic requires that the teacher follow the validity criteria, such as thematic richness, motivation, or relevance. We should note that the topics could be approached from a more academic to a less academic perspective.

A sample topic could be environmental education since it is important for the learner's academic and personal development, and its link with the world outside presents it as a socially relevant topic. Being a universal issue, the teacher of L2 English may find plenty of information and materials on the topic in different sources. S/he does not need to be a specialist in the topic; s/he needs to have some basic knowledge of the environmental damage and its consequences for the modern society. Concerning its suitability for learners' age, environmental issues seem to be appropriate enough for secondary students. This topic can be approached from more academic to less academic perspectives. Whilst a more academic perspective can be adopted in teaching the topic in natural science subjects, a less academic view can be also taken in teaching the ethics of the topic in the L2 classroom. In this less academic view, the foreign language teacher who implements CLIL does not need to be a content specialist. S/he only needs to have some general knowledge on the topic that allows him/her to focus on a less academic or more social side of the topic.

\section{Step 2. Control of the topic's linguistic potential}

This step is of utmost importance in the CLPS since the teacher validates the linguistic potential of the topic together with its adequacy to the official foreign language contents and objectives for the educational level. At this stage we may ascertain what the topic's 
potential is concerning some language related components, such as the sort of vocabulary it may enact, the language skills that it may draw forth, the external context of use in which it may be developed, including the type of register it may cover and some of the most typical genres used in the field.

Two related factors are fundamental in this step: (1) the extent to which the choice of a particular subject can determine the type of linguistic input (vocabulary and grammar) found in CLIL provision, and (2) the extent to which this subject selection can guarantee the learner's options for becoming communicatively competent.

On many occasions the main reason why learners are not offered enough opportunities to use language meaningfully in CLIL does not lie so much in the content chosen as in a poor processing of that content. In any CLIL model, the ideal situation would be one which could offer the learner an adequate degree of variation in linguistic input. Most people would agree that the subject of Natural Science would yield certain field-specific terms such as global warming, pole, or environment, as well as syntactic structures for describing processes in experiments. However, in language-oriented CLIL this type of language restrictions imposed by a particular topic needs to be overcome through different means in the selection and arrangement of L2 contents.

One of these means is the Common European Framework (Council of Europe, 2001). This document describes the context of language use on the basis of domains or "spheres of action or areas of concern [...] in which social life is organized" (p. 45), and situations particular of each domain. For the purposes of language learning and teaching at least four domains are distinguished, namely the personal domain, the public domain, the occupational domain, and the educational domain. They are all described in terms of a series of situational categories, such as the locations in which they occur or the social roles of the persons involved in the situation. Although it is not exhaustive but illustrative, the teacher may take this classification as a starting point for analysing the content and language possibilities of each subject.

As an example, in the topic of co-education, the four domains are represented. The personal domain of co-education refers, for example, to adults' attitudes about the assignment of household chores to boys and girls, or to the use or avoidance of certain stereotypical colours in children's clothes to identify gender. The public domain in coeducation is defined by aspects such as the discrimination of women and men in different public spaces, or the responsibility of the media in forging a specific typology of images of men and women, among others. An instance of lack of sex equality in the occupational domain could be the different treatment received by men and women in the labour market in terms of salaries. In education, co-education should be present in each subject, for example, the study of men and women in history, or the detection of sexist uses of language; and in the whole school, where possible hidden curricula against co-education should be detected and eliminated.

These domains trigger different registers and genres. The topic of environmental issues, for example, can be approached from different perspectives. For instance, work colleagues can chat at the office about the dangers of smoking on human health; a 50year-old man can read about the effects of his car air-conditioning system and its impact 
on the environment; or a baccalaureate student can write a paper about the greenhouse effect. In each case, the topic of environment is present through different kinds of users (work colleagues, 50 year old man, baccalaureate student), in different contexts (office, home, high school), and through different issues (impact of smoking on human health, impact of air-conditioner on the environment, and the greenhouse effect). Taking into account factors such as the learners' age or the general goals of CLIL teaching, this topic could be approached from an academic/scientific perspective. Based on the requirements established in the Real Decreto 1467/2007 (BOE, 2007) for Baccalaureate, we consider that a fruitful approach could be to adopt a formal-academic tone. Many of the objectives and contents of English as an L2 for this level address this formal, academic, and scientific language. Learners will have to make use of academic language (grammatical structures, discourse markers, technical and field-specific vocabulary) by producing formal written and oral texts that are typical of the academicscientific field, such as reports, summaries, or speeches.

In considering these aspects, the identification of field-specific vocabulary becomes crucial. Different techniques could be used for the selection of keywords in an objective way. For example, Pérez Basanta (2006) notes that it should be done in a systematic way by making use of some lexical analysis software. In the example of environmental issues for baccalaureate, we apply Lextutor Keywords software ${ }^{2}$ to a corpus of 20 publications (288,205 words) on environmental issues by Tunza, a United Nations Environment Programme aimed at young people ${ }^{1}$, and we obtain 388 keywords. Among the first 50 words, we find adjectives such as global, environmental, ecological, coastal, or indigenous; nouns such as pollution, dioxide, greenhouse, degradation, oceans, ozone, impacts, rainfall, arid, or extinction. Then, we use Paul Nation's Range software $^{3}$ to obtain the different ranges of frequency of the keywords according to 14 baseword lists consisting of 1,000 word families/each, arranged in terms of frequency. That is to say, they are the 14,000 most frequent word families in the English language. They are made out of the 10 million token spoken section of the British National Corpus (BNC). We also add baseword number 15 to cover proper nouns that correspond to the above-mentioned geographical zones not covered in former lists.

The tool identifies 388 types grouped in 336 families. Most types and families are in range 2, i.e. the first 2,000 most frequent English words, which seems adequate for Secondary or Baccalaureate students. In this range, we have obtained 79 tokens/types (20.36\%), and 67 families such as access, acid, Africa, agenda, Australia, behavior, connect, consume, damage, debt, energy, ensure, forest, fuel, generate, honour, international, monitor, overall, and promote. The next most frequent group of keywords belongs to range 1 with 68 types (17.53\%), and 53 families such as cent, centre, environment, favour, fish, food, invest, labour, protect, resource, transport, waste, active, affect, aware, brief, catch, clean, commit, or community. Types and families in ranges 3, 4, and 5 are the next most numerous. Overall, these results show that there are more high frequency words than low frequency words in the corpus selected. Leaving aside range $15,81.18 \%$ types, and $79.76 \%$ families appear in the first half of the ranges; and $61.85 \%$ types, and $59.2 \%$ appear in the first four ranges. 
The keywords spotted through this procedure should be used in the CLILQuest design later on. Moreover, the procedure we have followed for distinguishing the main keywords of the corpus could also be followed in dealing with individual texts. The teacher can identify the distinctive vocabulary of a given text, range it according to the above-mentioned frequency levels and, based on these words, s/he could design the CLILQuests for each module.

Step 3. Configuration of modules and CLILQuest design

As stated above, the task type of a CLILQuest is defined according to moduleintrinsic criteria. This means that the creation of a CLILQuest is primarily motivated by the content of each module not by its language. However, the linguistic features identified in previous steps, along with a series of thinking skills and language learning strategies, are also present in this content-oriented design. In Fernández Fontecha (2010b), we present a four-module CLILQuest programme for teaching climate change in Baccalaureate through English as a Foreign Language. Following, we explain the sample Introductory CLILQuest:

The CLILQuest in the Introductory Module, learners have to organise The First International Youth Conference on Climate Change. The organization of a conference can be taken as a product-based task that requires some inquiry into at least two main aspects: (1) the thematic scope covered by the topic of environmental issues and, specifically, by the subtopic of climate change, and (2) the procedure followed to organize a conference. The learners will play the role of members of the conference organizing committee. They will work in teams and will accomplish the assigned tasks. At the end of the task, they have to get some specific outcomes, such as an itinerary to places of interest in the region, the conference programme, or the conference blog or website. Five quests develop this CLILQuest: the first three quests are simultaneous and carried out by the different teams; the rest of quests are accomplished by all groups sequentially.

This CLILQuest contains a test section in order to activate learners' background knowledge on climate change and some of its key terms. The test comprises three distinct sections, namely a section for open questions of the kind "Can you provide the Spanish terms for each of these terms: climate change, global warming, greenhouse effect, or ozone layer?" or "Do you know what climate change is? Think about what you learned in your natural science classes and explain in your own words what climate change is"; a mixed section for true-false questions, such as "The greenhouse gases that exist naturally in the air are the reason why the earth's normal temperature is not at least $30^{\circ} \mathrm{C}$ cooler (True)", and a final section for matching questions where the learners have to find the right definition for five terms, specifically greenhouse effect, global warming, Kyoto protocol, IPCC, and climate change. In these questions, the learners have to work with a selection of keywords extracted from a Lextutor analysis. In case the learners need some help with the questions, they can have access to a selection of web glossaries and other links that contain the solutions. In this section, as an optional reading warm-up, we include the comic We Are for Our Climate, published by the 
World Meteorological Organization in 2004. The vocabulary that appears in this test section will be used in the rest of modules.

Based on Anderson and Krathwohl's (2001) adaptation of Bloom's taxonomy of educational objectives, the main objective of this module is to develop factual knowledge, i.e. main terms and specific details, about environmental issues and more specifically about climate change. However, the learners are also learning specific procedural knowledge about conference organization.

There is a number of thinking skills identified in this CLILQuest, such as understand, when learners have to collect and classify information on possible conference venues; evaluate, when learners have to make judgments about the possible venues; or create, in planning and creating a tour, or in developing the conference programme. The work done in this introductory CLILQuest will be continued in the Core-Knowledge CLILQuest, where learners become the keynote speakers of the conference.

Finally, in deciding how to integrate this programme in a sort of ICT instruction delivery mode, we are setting the interface through which learners will interact. Depending on the learners' age and educational level, we may consider choosing an elearning or a blended-learning delivery mode. In our opinion, e-learning is neither workable nor desirable for levels below post-secondary education, where a kind of faceto-face contact is preferable to better handle the situation, assist problematic learners, support different learning styles, and provide adequate scaffolding measures. Against a pure e-learning mode, blended-learning can offer a good means towards the integration of the new technologies into conventional instruction (Bartolomé, 2004; Derntl and Motschnig-Pitrik, 2005; Marsh, Mcfadden and Price, 2003).

\section{Conclusions}

This paper has described the Content and Language Processing Sequence (CLPS), a tool for assisting syllabus planning and delivery in language-oriented versions of CLIL. This tool addresses issues like content and language processing. It pays special attention to mechanisms for controlling the foreign language behind the selected contents. This CLPS is composed of the Topic-Module-CLILQuest sequence. An important characteristic of this sequence is that it allows the teacher to control the language at each step of content selection and task design.

Some future work should be done with regard to the framework that we have created for undertaking a technology-enhanced CLIL model. The CLPS should be evaluated in the actual classroom. Regardless of the outcomes on the validity of the framework, we should also note some possible areas for further development. As an example, the framework should be refined to provide specific recommendations on learners' evaluation. Another aspect that deserves special attention is the means of coping with the different types of Focus on Form. We have only suggested a way to include some FonF part in the CLILQuest; however, we are aware that further 
explanation is needed to determine when, where, and how the different types of FonF should be applied in the accomplishment of the quests.

In sum, although this framework may suit the requirements of the content or language teacher, one of its main aims is that the foreign language teacher has an active role in CLIL implementation by taking advantage of some core aspects of CLIL.

\section{Notes}

1. Website at http://www.unep.org/Publications/contents/Tunza.asp (Retrieved March 12, 2012)

2. Lextutor is developed by Tom Cobb at the University of Québec in Montreal. Website at http://www.lextutor.ca/ (Retrieved March 12, 2012).

3. Website at http://www.victoria.ac.nz/lals/staff/paul-nation/nation.aspx (Retrieved March 12, 2012).

\section{References}

Anderson, L. W. and D. R. Krathwohl (eds.) (2001): A Taxonomy for Learning, Teaching, and Assessing: a Revision of Bloom's Taxonomy of Educational Objectives. New York: Longman.

Bartolomé, A. (2004): "Blended Learning. Conceptos básicos." Pixel-Bit. Revista de Medios y Educación 23: 7-20.

Bax, S. (2003): “CALL - past, present and future." System 31(1): 13-28.

Bloom, B.S. (ed.) (1956): Taxonomy of Educational Objectives, the Classification of Educational Goals - Handbook I: Cognitive Domain. New York: McKay.

BOE (2007). Real Decreto 1467/2007, of 2 November, por el que se establece la estructura del bachillerato y se fijan sus enseñanzas mínimas. (Boletín Oficial del Estado No. 266, of 6 November).

Brinton, D.M., Snow, M. A., and M. B. Wesche (2004): Content-based Second Language Instruction. New York: Newbury House.

Chambers, A. and S. Bax (2006): "Making CALL work: Towards normalisation." System 34(4): 465-479.

Chamot, A.U. and J.M. O'Malley (1987): “The cognitive academic language learning approach: A bridge to the mainstream. TESOL Quarterly 21(2): 227-249.

- (1994): The CALLA handbook: Implementing the Cognitive Academic Language Learning Approach. Reading, MA: Addison Wesley.

Council of Europe (2001): Common European Framework of Reference for Languages: Learning, Teaching, Assessment. Council of Europe Modern Languages Division, Strasbourg: Cambridge University Press.

Coyle, D., P. Hood and D. Marsh (2010): Content and language Integrated Learning. Cambridge: Cambridge University Press

Cummins, J. (1980): "The cross-lingual dimensions of language proficiency: Implications for bilingual education and the optimal age issue." TESOL Quarterly 14(1): 175-187. 
(1984): Bilingualism and Special Education: Issues in the Assessment and Pedagogy. Clevedon, England: Multilingual Matters.

(1998): "Immersion education for the millennium: What have we learned from 30 years of research on second language immersion?." In M. R. Childs and R. M. Bostwick, eds., Learning Through Two Languages: Research and Practice. Second Katoh Gakuen International Symposium on Immersion and Bilingual Education. Katoh Gakuen, Japan, 3447.

Curtain, H. and M. Haas (1995): Integrating Foreign Language and Content Instruction in Grades K-8. ERIC Digest 381018. Washington: ERIC Document Reproduction Service.

Dalton-Puffer, C. (2008): "Outcomes and processes in Content and Language Integrated Learning (CLIL): current research from Europe." In W. Delanoy and L. Volkmann, eds., Future Perspectives for English Language Teaching. Heidelberg: Carl Winter, 139-157.

Derntl, M. and R. Motschnig-Pitrik (2005): "The role of structure, patterns, and people in blended learning." The Internet and Higher Education 8(2): 111-130.

Dodge, B. (2001): "FOCUS: Five rules for writing a great WebQuest." Learning and Leading with Technology 28(8): 6-9. Retrieved June 5, 2007, from: http://webquest.sdsu.edu/documents/focus.pdf

Doughty, C. J. and M. H. Long (2003): "Optimal psycholinguistic environments for distance foreign language learning." Language Learning \& Technology 7(3): 50-80.

Echevarria, J., M. Vogt and D. Short (2000): Making Content Comprehensible for English Language Learners: the SIOP Model. Boston: Allyn and Bacon.

Eurydice (2006): Content and Language Integrated Learning (CLIL) at school in Europe. Brussels: Eurydice European Unit.

Fernández Fontecha, A. (2010a): "First Steps of CLIL in a Spanish Monolingual Community: The Case of La Rioja." In Y. Ruiz de Zarobe and D. Lasagabaster, eds. CLIL in Spain: Implementation, Results and Teacher Training. Newcastle, UK: Cambridge Scholars Publishers, 79-94.

- (2010b): "The CLILQuest: a Type of Language WebQuest for Content and Language Integrated Learning (CLIL)." CORELL: Computer Resources for Language Learning 3 (2009-2010): 45-64. Ton Koenraad (ed.) Monograph: LanguageQuests in Language Education.

(2009): "Spanish CLIL: Research and Official Actions." In Y. Ruiz de Zarobe and R. M. Jiménez Catalán, eds. Content and Language Integrated Learning: Evidence from Research in Europe. Clevedon: Multilingual Matters, 3-22.

(2008a): "Review of CLIL implementation tools: the forgotten factor." In A. Shafaei, and M. Nejati, eds., Global Practices of Language Teaching: Proceedings of the 2008 International Online Language Conference (IOLC 2008). USA: Universal Publishers, 3850.

(2008b): Teacher perceptions on Spanish CLIL provision. Paper accepted for CLIL Fusion, International CLIL Conference, Tallinn, Estonia.

Fernández, R., C. Pena, A. García and A. Halbach (2005): "La implantación de proyectos educativos bilingües en la Comunidad de Madrid: las expectativas del profesorado antes de iniciar el proyecto." Porta Linguarum 3: 161-173.

Gianelli, M. C. (1997): “Thematic units: Creating an environment for learning.” In M. A. Snow and D. M. Brinton, eds. The Content-based classroom: Perspectives on Integrating Language and Content. New York: Addison Wesley Longman, 142-148. 
Gillespie, J., and J. McKee (1999): "Does it fit and does it make any difference? Integrating CALL into the curriculum." Computer Assisted Language Learning 12(5): 441-445.

Hartiala, A. K. (2000): Acquisition of Teaching Expertise in Content and Language Integrated Learning. Doctoral Dissertation. University of Turku, Turku: Painosalama Oy.

Irujo, S. (1990): How to Plan Content-based Teaching Units for ESL. ERIC Report 320452. Washington: ERIC Document Reproduction Service.

Jonassen, D. H. (1994): "Thinking technology: Toward a constructivist design model." Educational Technology 34(3): 34-37.

Junta de Andalucía (2008): El Currículum Integrado De Las Lenguas. Sevilla: Consejería de Educación Retrieved March 2, 2012, from http://www.juntadeandalucia.es/averroes/ impe/web/contenido?pag=/contenidos/B/InnovacionEInvestigacion/ProyectosInnovadores/ Plurilinguismo/Seccion/CVIntegrado/cil

Kidd, R. and B. Marquardson (1993): Sourcebook: For Integrating ESL and Content Instruction using the Foresee Approach. Winnipeg: Manitoba Education Citizenship and Youth.

(1994): Secondary Sourcebook: For Integrating ESL and Content Instruction using the Foresee Approach. Winnipeg: Manitoba Education Citizenship and Youth.

Koenraad, A.L.M. and G.J. Westhoff (2003): Can you tell a LanguageQuest when you see one? Design critera for TalenQuests. Paper presented at the 2003 Conference of the European Association for Computer Assisted Language Learning: EUROCALL 2003. Limerick: University of Limerick, Ireland, 3-6 September 2003.

Jonassen, D.H. (1994): "Thinking technology: Toward a constructivist design model." Educational Technology 34(3): 34-37.

Langé, G. (eds.) (2002): TIE-CLIL Professional Development Course. Milan: M.I.U.R. Direzione Regionalle della Lombardia on behalf of the TIE-CLIL Project.

Levy, M. (2007): "Culture, culture learning and new technologies: Towards a pedagogical framework." Language Learning and Technology 11(2): 104-127.

Llovet, X. (2007): E/LE en Europa: El caso de la perspectiva del docente en un enfoque integrado de contenidos y lenguas extranjeras (EICLE), Memoria de máster (Universidad de Barcelona, 2005). RedELE: Revista Electrónica de Didáctica ELE 7. Retrieved August 2, 2007, from http://www.mec.es/redele/ Biblioteca2007/XavierLlovet.shtml

Long, M.H. (1998): "Focus on form in task-based language teaching." University of Hawai'i Working Papers in ESL 16(2): 35-49.

March, T. (2000): "WebQuests 101. Tips on choosing and assessing WebQuests." Multimedia Schools 7(5): 55-58. Retrieved June 7, 2007, from: http://www.infotoday.com/MMSchools/oct00/march.htm

- (2003): What WebQuests Are (Really). Retrieved June 7, 2007, from: http://bestwebquests.com/what_webquests_are.asp

Marsh, D., A. Maljers and A.-K. Hartiala (2001): Profiling European CLIL Classrooms Languages Open Doors. Jyväskylä: University of Jyväskylä.

Marsh, D. (2002): CLIL/EMILE - The European Dimension: Actions, Trends and Foresight Potential. DG Education \& Culture, European Commission. Retrieved November 20, 2006, from http://ec.europa.eu/education/policies/lang/doc/david_marsh-report.pdf

Marsh, D. and B. Marsland (1999): Learning with Languages. University of Jyväskylä.

Marsh, G.E. II, A.C. Mcfadden and B. Price (2003): "Blended instruction: Adapting conventional instruction for large classes." Online Journal of Distance Learning Administration 6(4). 
Martin, I. (1990): "The methodology of the module: a content-based approach.” In A. Sarinee, ed., Language teaching methodology for the 1990s. Singapore: SEAMEO Regional Language Centre, 97-105.

Marzano, R. J. (2001): Designing a New Taxonomy of Educational Objectives. Thousand Oaks, CA: Corwin Press.

McCarthy B. (1999): "Integration: The sine qua non of CALL." CALL-EJ Online 1(2). Retrieved May 4, 2006, from: http://www.tell.is.ritsumei.ac.jp/callejonline/jour nal/1-2/mccarthy.html

Mehisto, P., D. Marsh and M.J. Frigols (2008): Uncovering CLIL. Oxford: Macmillan Publishers Limited.

Met, M. (1998): "Curriculum decision-making in content-based teaching." In J. Cenoz and F. Genesee, eds., Beyond bilingualism: Multilingualism and multilingual education. Clevedon, England: Multilingual Matters Ltd., 35-63.

Mohan, B. (1986): Language and Content. Reading, MA: Addison-Wesley.

Nikula, T. (1997): The Terminology of 'Content and Language Integrated Learning'. EUROCLIC Bulletin, 2. Retrieved February 18, 2006, from: http://www.euro clic.net/index.php?inhoud=inhoud/bulletins/bulletin2/3.htm

Oliver, R. (2001): "Developing e-learning environments that support knowledge construction in higher education." In S. Stoney and J. Burn, eds., Working for Excellence in the E-conomy. Churchlands: Australia, We-B Centre, 407-416. Retrieved September 3, 2007, from: http://elrond.scca.ecu.edu.au/oliver/2001/ webepaper.pdf

Opp-Beckman, L. (2002): “Africa online: A web-and content-based English language teaching course.” TESOL Journal 11(3): 4-8.

Pérez Basanta, C. (2006): ADELEX: Evaluación y desarrollo de la competencia léxica a través del aprendizaje virtual y WebCT. Seminario Evaluación del vocabulario a través de la tecnología. June 2006. Logroño: Universidad de La Rioja

Pérez Torres, I. (2006): Diseño de Webquests para la enseñanza/aprendizaje del inglés como lengua extranjera: aplicaciones en la adquisición de vocabulario y la destreza lectora. MA Dissertation. Granada: Editorial Universidad de Granada.

Raphan, D. and J. Moser (1993/1994): "Linking language and content: ESL and art history." TESOL Journal 3(2): 17-21.

Räsänen, A., T. Kaasik, H.D. Mathews, H. Oresik and S. Sentocnik (1996): Profile of teacher qualifications required for bilingual education programmes, Report on workshop 12B, Bilingual education in secondary schools: Learning and teaching non-language subjects through a foreign language. Echternach, Luxemburg: Council of Europe, 277-292.

Reinhardt, J.K. and Isbell (2002): "The recycling research documentary: A technologyintegrated project." TESOL Journal 11(3): 41-48.

Richards, C. (2005): "The design of effective ICT-supported learning activities: Exemplary models, changing requirements, and new possibilities." Language Learning and Technology 9(1): 60-79.

Snow, M.A., M. Met and F. Genesee (1989): "A conceptual framework for the integration of language and content in second/foreign language instruction." Tesol Quarterly 23(2): 201217.

Stoller, F. (2008): "Content-based instruction." In N.H. Hornberger, ed., Encyclopedia of Language and Education, Vol. 4: Second and Foreign Language Education. New York: Springer, 59-70. 